\title{
The Urgency of Village Mediation Institution as a Mechanism for Dispute Resolution: The Case of Wukirsari Village in the Special Region of Yogyakarta
}

\section{Urgensi Lembaga Mediasi Desa sebagai Mekanisme Penyelesaian Sengketa: Kasus Desa Wukirsari di Daerah Istimewa Yogyakarta}

\author{
Ilham Yuli Isdiyanto $^{1 *}$, Anom Wahyu Asmorojati ${ }^{2}$
}

${ }^{1}$ Law Faculty, Universitas Ahmad Dahlan, Jl. Ringroad Selatan, Kragilan, Tamanan, Banguntapan, Bantul, D.I. Yogyakarta, Post Code 55191, Indonesia

${ }^{2}$ Law Faculty, Universitas Ahmad Dahlan, Jl. Ringroad Selatan, Kragilan, Tamanan, Banguntapan, Bantul, D.I. Yogyakarta, Post Code 55191, Indonesia

*)Corresponding author: ilham.isdivanto@law.uad.ac.id

Received: January 19, 2021 | Revised: June 30, 2021 | Accepted: July 14, 2021 | Online publication: August 23, 2021

\begin{abstract}
This research discusses an important issue in the rural administration, that is the urgency of institution transformation of the status and position of the Village Head in dispute resolution among villagers. The purpose of this research is to highlight the urgency of institutionalization of dispute resolution through the Village Mediation Institution. The first concern is to find the status and legal basis of the Institution; the second is to describe the urgency of establishing this institution as a dispute resolution mechanism among villagers; and the third is to build the model or system that matches with the condition in Wukirsari. The research method used was a normative-empirical-concept and the data were analyzed qualitatively to be presented as a descriptive-prescriptive analysis. The result of this research shows that there is an urgency for Wukirsari Village government to form a Village Mediation Institution due to socio-geographic considerations and also as an implementation of Article 26 paragraph (4) letter K of Village Law No. 6 of 2014. The Village Mediation Institution in Wukirsari Village should consist of a balance composition between the elements of Village Government and professionals so that it will become an effective and efficient institution in resolving disputes among the members of Wukirsari Village society.
\end{abstract}

Keywords: dispute resolution, village head, village mediation institution

\section{ABSTRAK}

Penelitian ini membahas masalah penting dalam pemerintahan desa, yaitu urgensi transformasi kelembagaan atas status dan kedudukan Kepala Desa dalam penyelesaian sengketa di antara warga desa. Tujuan penelitian ini adalah menyoroti urgensi pelembagaan penyelesaian sengketa yang dijalankan oleh Kepala Desa menjadi Lembaga Mediasi Desa. Untuk itu, fokus pertama artikel ini adalah menelusuri status dan dasar hukum dari kelembagaan tersebut; kedua adalah memaparkan urgensi pembentukan kelembagaan tersebut sebagai mekanisme penyelesaian sengketa di antara warga desa; dan ketiga adalah membangun model atau sistem kelembagaannya yang sesuai untuk kondisi di desa Wukirsari. Metode penelitian ini menggunakan pendekatan normatif-empiris-konseptual dan data yang diperoleh dianalisis secara kualitatif kemudian disajikan secara deskriptif-preskriptif. Hasil penelitian ini menunjukkan bahwa pemerintah Desa Wukirsari memiliki urgensi untuk membentuk Lembaga Mediasi Desa berdasarkan pertimbangan sosio-geografi yang dihadapi dan juga sebagai implementasi atas amanat ketentuan Pasal 26 ayat (4) hurufk Undang No. 6 tahun 2014 tentang Desa. Penelitian ini mengusulkan model Lembaga Mediasi Desa di Desa Wukirsari yang mencerminkan perimbangan antara unsur Pemerintah Desa dan Profesional sehingga dapat berjalan efektif dan efisien dalam penyelesaian perselisihan di antara masyarakat Desa Wukirsari.

Kata kunci: penyelesaian sengketa, kepala desa, lembaga mediasi desa

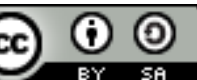

Content from this work may be used under the terms of the Creative Commons Attribution-Share A like 4.0 International. Any further distribution of this work must maintain attribution to the author(s) and the title of the work, journal citation and DOI.

Published under Department of Communication and Community Development Science, IPB University and in association with Ikatan Sosiologi Indonesia

E-ISSN: 2302-7525 | P-ISSN: 2302-7157 


\section{INTRODUCTION}

The story about the weaknesses of the justice system in Indonesia is no longer a secret, such as long-time process, high costs, and complexities that contradict the principle of fast, cheap, and simple trial process, not to mention the rigid and procedural proofing process which only pursues procedural justice rather than substance justice or material aspects of each case (Taufiq et al., 2017). These problems have not ended yet. The justice system in Indonesia is preoccupied with an endless pile of cases. Data on cases at the first level that entered the Supreme Court in 2009 alone had reached 3,546,854 cases, which were dominated by cases under general courts (Mahkamah Agung Republik Indonesia, 2010).

In the Supreme Court's report, an internal study stated that there are at least three main issues that now become the main focus, namely; the length of the litigation process that makes costs unpredictable, the lack of understanding between justice seekers and court users regarding the procedures, documents, and the necessary requirements, and also the lack of public trust in the judiciary (Mahkamah Agung Republik Indonesia, 2010). From these three things, the most crucial is the lack of public trust in the judiciary; how can the judicial system work effectively and be implemented efficiently if the judiciary itself cannot be trusted. This certainly has an impact on the aspects of legal enforcement and also legal awareness in society. In fact, the Indonesia Corruption Watch (ICW) report states that in the last 6 years, around 28 officials in the judiciary have been arrested by the Corruption Eradication Commission (KPK) consisting of 18 judges and 10 non-judge officials (Erdianto, 2018). There are many gaps in the judiciary, especially related to administration management of cases, which are often exploited by irresponsible individuals (Rahmatullah, 2017).

Because of the foregoing events, a new reflection emerges: there needs to be an alternative justice-seeking system that is able to accommodate the needs of justice seekers, especially that reach the needs of the Indonesian people. One of them is to re-optimize the role of the village to be present in solving the problems of its citizens, where the Village Head functions and acts as a 'mediator' to help solve the social problems. This is not certainly without any reason, for the provisions of Article 26 Paragraph (4) letter k of Law Number 6 of 2014 concerning Villages explicitly state that the Village Head is obliged to resolve village society disputes.

The role of the village in dispute resolution represents the spirit of the village as previously there was the term pamegat or sang pamegat which is usually abbreviated as samgat which means the breaker or judge (Muljana, 2006: 223). This spirit also appears in a Javanese proverb; desa mawa cara, negara mawa tata which means that the village is autonomous, independent and has its own way according to the social system and local wisdom; thus it is free from state intervention (Basuki, 2017).

Even though the function and role of the Village Head is very strict as a problem solver of the village society as regulated in Law Number 6 of 2014 concerning Villages, the form and system of settlement is still unclear and firmly regulated in this law and its derivative laws. In this relation, there is a plan from Wukirsari Village, Imogiri District, Bantul Regency to accommodate the implementation of Article 26 paragraph (4) letter k of Law Number 6 of 2014 to establish a Village Mediation Institution as a forum to resolve various problems of the Wukirsari Village society in a mediation way. However, the problem is what is the position, form and institutional status of the Village Mediation Institution in the village system and the national legal system, especially since the mediation aspect is also specifically regulated in Supreme Court Regulation No.1 of 2016 concerning Mediation Procedures in Courts. In fact, the question arises whether this Village Mediation Institution is also part of the Alternative Dispute Resolution as regulated by Law Number 30 of 1999 concerning Arbitration and Alternative Dispute Resolution.

Based on the discussion above, this research is an effort to search and find out the institutionalization of the mediation mechanism at the village level in the legal system in Indonesia, especially by establishing a village regulation on Village Mediation Institution. In addition, this research also aims to present the empirical situation in Wukirsari Village in terms of its social dynamics; therefore, it indicates that there is an urgency or need to establish a Village Mediation Institution. Lastly, this research will propose the structure and model of the Village Mediation Institution to be formed in Wukirsari Village.

This research is very important because the results will not only be useful for Wukirsari Village, but also become a prototype or pilot project for the concept of Village Mediation Institution throughout Indonesia. Also, because the Indonesian judicial system (litigation) is a win-lose solution that often creates new problems, takes a long time and is costly (Ningsih et al., 2019), a different approach is needed, like a win-win solution through the mediation channel which can be institutionalized locally by the village administration, especially in civil cases and/or minor criminal cases which are still legally possible for mediation.

Sodality: Jurnal Sosiologi Pedesaan | Vol. 9 (02) 2021 


\section{METHOD}

Like a usual legal research, this research is a normative research or at least one which leads to normativism (Marzuki, 2010: 55). Until now there has been no definitive legal research method; thus, the scientific method basically depends on the formal object of the concerned research (Bakker \& Zubair, 1990: 28).

1. Approach

Following the research topics, this research uses several approaches as follows:

a. A normative or statute approach, that is reviewing regulations such as laws and regulations under them (Marzuki, 2010: 93);

b. The empirical approach, which is an approach that is carried out by assessing the actual situation in society concerning facts related to research (Benuf \& Azhar, 2020)

c. The conceptual approach, which analyzes the concepts and motives behind the development of values and norms that are in accordance with the concept behind it. This approach is important for constructing a form or model based on existing values or norms.

2. Data Collection Method

This method is carried out by conducting field studies and literature studies that use not only primary and secondary legal materials but also primary data which is obtained by interviews.

3. Data Analysis Technique

Primary and secondary data and legal materials obtained during field studies will be analyzed in a narrative or descriptive way that focuses on the quality side (descriptive-qualitative). Furthermore, the descriptive-qualitative aspects described are then finally concluded in a descriptively-prescriptive way so that they do not lose the doctrinal aspects of legal science. (Darumurti, 2017).

\section{RESULTS AND DISCUSSION}

\section{Profile and Socio-Geography of Wukirsari Village}

Wukirsari Village, Imogiri District, Bantul has many objects of attraction, especially those related to tourism development. Batik is one of the mainstay icons in this village, one of which is Giriloyo written batik in Giriloyo, Wukirsari (Nursaid \& Armawi, 2016). Besides being famous for their Batik, craftsmen also make tatah sungging (carvings) from cow, buffalo, or goatskin that are made into various kinds of crafts such as puppets, fans, and lampshades (Siswanta, 2008). Another place is Pucung, Karangasem which is also famous for its unique handicraft such as tatah sungging for shadow puppets because there is a morphological process with affixation of dikuwuk and ngebrom (Riffai \& M, 2018).

Located approximately $15 \mathrm{~km}$ from Yogyakarta City, Wukirsari Village with an area of 15,385,504 ha and a population of approximately 17,245 people (Pemerintah Kabupaten Bantul, n.d.) has a lot of potentials. The name 'wukirsari' itself holds beauty, which means the form of a beautiful mountain; geographically the beauty of Wukirsari Village cannot be denied. With an area surrounded by beautiful mountains thus, it becomes a magnet for travelers who want to enjoy beautiful nature.

Like a village society in general, the people of Wukirsari Village are communal who prioritize togetherness (guyub) so that they have a close relationship with each other (Widihastuti \& Kusdarini, 2013). This can be seen from the mutual cooperation that is still maintained in various forms of activities, such as njurung (Javanese), which is involved when relatives or villagers carry out circumcision, marriage, or other forms of activities such as Mudo Palupi, Majemuk, Nyadran, and Wali Kutuban (Widihastuti \& Kusdarini, 2013). This communal nature with the spirit of mutual cooperation has an impact on strong emotional relationships with each other, then if disputes arise, they should be resolved in a kinship manner and not against the spirit of guyub.

As a village that maintains communal values and togetherness, it does not mean that the interaction of its citizens is free from social friction or various kinds of disputes that exist in society. According to Fery 
Sanawan, the Head of the Wukirsari Village Administration, cases of legal violations that have appeared include theft, affair, and land disputes (Sanawan, 2020). The causing factors also varied, Fery continued that the theft was clearly due to economic factors. However, the affair could occur because of the distance since one (husband or wife) is outside the region and even abroad. But, the causes of divorce are various. In the case of land disputes the factor is due to the uncertainty of the land rights, such as the form of inheritance distribution and land measurement. This problem is dominated by inheritance distribution (Sanawan, 2020).

Even so, according to Fery, the social situation in Wukirsari Village is still relatively good, especially the one related to tolerance because it still upholds a local culture. The existence of the Pamong who always tries to help solve various problems that exist in society. Sometimes these efforts do not always gain maximum results, such as in 2019 when the Village Government together with the guardians tried to solve the problem of an affair, but it turned out that one of the perpetrators ended up committing suicide because he was embarrassed by the wife and the village people (tribratanewsbantul, 2019). This is certainly in accordance with the culture of the Javanese people who feel embarrassed (kisinan / kewirangan), so that they are excluded from their society as a result of their own actions (ngunduh wohing pakarti), and they can't do anything else except improving themselves (Soehadha, 2014). However, in this context, it seems that the suicide happened because he did not have self-esteem so he preferred to die.

Regarding the geo-social nature of Wukirsari Village which is still inherent in its traditional character, Pamong has a central role that can't be replaced. Referring to KBII Online, Pamong means caregivers, educators, administrators (Badan Pengembangan dan Pembinaan Bahasa, 2016). From the perspective of the Wukirsari society, the term pamong has a deeper meaning. As expressed by one of the society leaders in Wukirsari Village Suyono, who is the owner of the Omah Wayang studio, Pamong is defined as:

"Pamong desa in the Javanese Language comes from the word pamong; pemomong which means that it can acknowledge the citizens of the society. Pamong must be able to nurture citizens, from inappropriate, unfavorable behavior, the village Pamong must be able to deal with the people's complaints." (interview with Suyono, Wukirsari Village, 07/07/2020)

Pamong becomes the foundation of society in Javanese tradition; its existence is to help social stability so that balance and harmony in society can be established. This concept is called mangku which is a social psychological characteristic based on cultural aspects. Society must be kapangku (embraced) so that they are able to be controlled. This is revealed symbolically in the Javanese script philosophy; Aksara Jawi punika menawi kapangku dados pejah (if there is kapangku symbol, the javanese script would be read as a consonant) (Priyatingsih, 2019). This concept of holding is also symbolized in various royal titles such as Hamengku Buwono (World Leader) and Mangkunegaran (State Leader).

\section{Village Mediation Institution as a Dispute Resolution Mechanism}

Village entities as autonomous entities face various challenges, both internally and externally. Internally, the most important challenges are human resources in the government management and social participation level. The village government is rarely able to manage rural social capacity to be a social capital; therefore, they cannot maximize its potential properly. While externally, the role of village government is more dominated by the role of the local government and the central government (supra village), although there are also nongovernmental factors. Moreover, these external factors are the cause of the emergence of various biases in the village or according to Robert Chambers (1979) the village as victims of overturning (putting the last first) (Maschab, 2013: 12). According to Mashuri Maschab, the concept of the village itself has three interpretations (Basuki, 2017): First, the sociological definition, which is a phenomenon of a society or community that living and settling in an area where the lifestyle tends to be homogeneous; Second, the economic definition, as a phenomenon of society that tries to fulfill the needs of everyday life from what is provided by nature; and Third, the political definition, the village as a government organization or political power has the authority and part of the state government. The three definitions developed by Mashuri Maschab emphasize more on its traditional aspects. It is somewhat old and still follows the image of the village as a beautiful place in an area far from urban areas. 
The understanding of village as a pure tradition is a hope for the ideal form of the village, but on the other side, the development of the industrialized economy, internet, and the penetration of cultures from various parts of the world have had quite a serious impact on rural development. In fact, we can observe the emergence of 'transitional areas' or commonly referred to as sub-urban. The term suburban is often understood as the condition of urban areas which simultaneously shows the rural characteristic as well; on the one hand, it is urban and on the other hand, it is rural (Sukirno \& Harianto, 2017). However, it is not only an urban or city that contains the appearance of a rural characteristic, the opposite can also happen. The term suburban itself simply indicates the meaning of suburbs, which means traditional and modern assimilates. But this understanding can no longer be limited to the rural area - the suburbs.

Technology has succeeded in deconstructing the understanding of space and boundaries because today even other villages with developing information technology can turn into suburban areas due to the penetration of modern culture that can be accessed through gadgets. It can be seen at work that youths are no longer required to pursue local economic needs such as farming or being craftsmen as mentioned earlier as a characteristic of Wukirsari Village. According to Susilo, as the Village Head, most of the productive age villagers in Wukirsari Village are looking for work outside the village or even outside the region. This happens because of the narrow working space in Wukirsari Village. According to observations, what is meant by working space here is still interpreted in terms of industrialization, because there are actually a lot of jobs that can be developed in Wukirsari Village.

The entry of technology brings a fast and uncontrollable flow of information. All humans who are connected to the internet deconstruct their existence by tying themselves not only to reality space but also to cyberspace. Even in cyberspace there is no state territorial boundary, so the state finds it difficult to control the flow of constructive or destructive information because it will quickly spread within seconds (Yuli Isdiyanto, 2019: 2). Therefore, through the world of cyberspace, there is also no boundary between modern and traditional areas, urban and rural areas; all become one in the world village or commonly referred to as globalization. From this phenomenon, it can be illustrated that all rural societies - including the people of Wukirsari Village - can take any information that affects their attitudes and mindsets; therefore, the boundaries of urban and rural areas or the transition to sub-urban are biased in this perspective. The result is a tendency for a homogeneous village society to change into a heterogeneous or complex society with various interests which lead to individualistic attitudes. From here, friction over social interactions can often arise in accordance with their interests so that the foundations of existing values and norms need to be used as the basis for social control.

Conflict is a clash between two or more parties due to differences in values, status, power, or others so that conflict and social life are very difficult to separate (Indriana et al., 2016). Every conflict or dispute that arises in the society needs to be resolved as a guarantee of social stability and social order, referring to the legal system in Indonesia. In general, there are two forms of dispute resolution that can be used: litigation and nonlitigation. The litigation or judicial route is dispute resolution through a formal legal way involving law enforcement elements such as judges, prosecutors, police, and lawyers.

The advantages of the litigation are: a) Legal certainty, because formal law is written and more specific it can create legal certainty and high predictability, so that the dynamics of life in society are 'predictable' (Asshiddiqie, 2011). As said by Scholten, humans can't bear uncertainty, so the law must be constant and certain (Scholten, 2002: 20); b) Executing character, the litigation system with its existing instruments has the authority to carry out the execution of an existing decision if one of the parties tries to oppose or reject the decision. Thus, if there is a disagreement, then the legal instrument has the power to force the execution of the existing decision. There are actually many other advantages, but these two things are the most important, although that does not mean that the litigation way is not weak. In fact, the weaknesses include: the cost is high, it takes more time, not all matters are kept secret, and it is the win or lose system. Even the certainty aspect which is the advantage of the litigation system is actually not definite. Empirically the formal legal system faces a "ghost of uncertainty" which is often done by law enforcers themselves, as stated by Mahfud Md (Dil, 2019). The "ghost of uncertainty" refers to a condition where the law is supposed to provide certainty, but due to various ' $\mathrm{x}$ factors' there is a mal-system that creates legal uncertainty; one of the causes is the corrupt behavior of law enforcers. 
In Indonesia, the power system refers to the concept of distribution of power instead of separation of power (Yani, 2018). So, when referring to this system, the existing Institutions are not absolutely separated in their authority, such as the judicial power (Constitutional Court) which also makes new norms (ultra petita). The President also has a legislative authority by making laws and regulations (Regulation in Lieu of Law/Perpu). In a separation of power system, where certain authorities are only tied to one institutional form, such as a president who only implements laws without being able to make them (e.g.: unable to make Regulation in Lieu of Law/Perpu), the government system will be more rigid and difficult. Therefore, the judicial paradigm can also experience a shift not only in the judiciary Institution, although currently it is still dominated by the judiciary Institution.

On the other hand, there is a non-litigation or non-judicial resolution system; it is the resolution outside the court which is more on a familial deliberation approach and a win-win solution, not a win or lose solution. One form of dispute resolution is the mediation method because it has advantages, namely (Rahayu et al., 2016) (1) it has relatively cheaper cost with faster settlement; (2) it has more satisfactory results for the parties; (3) it is a comprehensive agreement (procedural and psychological); (4) it can improve communication between the conflicting parties; (5) it maintains a friendship or ends it in a more friendly manner; (6) it helps release anger and increase awareness of each other position; (7) it gives easier decisions to implement and (8) it produces better agreements than a win-lose solution. However, on the other hand, the non-litigation resolution procedure contains misunderstandings namely: (1) it is easy to deny because of the form of an agreement; (2) it does not have an executorial instrument; (3) it needs special skills to make a comprehensive peace agreement, and (4) the wrong mediation technique will cause new problems.

Mediation, in general, can indeed be said to be a part of alternative dispute resolution as regulated in Law Number 30 of 1999 concerning Arbitration and Alternative Dispute Resolution. In the provisions of Article 1 point 10 of a quo law, it is stated, "Alternative Dispute Resolution is a dispute resolution Institution or difference of opinion through a procedure agreed upon by the parties, that is settlement outside the court by consultation, negotiation, mediation, conciliation, or expert judgment."

Referring to these provisions, the position of mediation as a part of non-litigation has been legally recognized. Furthermore, in the provisions of Article 6 paragraph (3) of Law Number 30 of 1999 the position of an expert advisor or a mediator is also stated,"The dispute or difference of opinion as referred to in paragraph (2) can't be resolved, so with the written agreement of the parties, the dispute or difference of opinion is resolved through the assistance of one or more expert advisors or through a mediator."

However, Law No 30 of 1999 does not specify in detail what is meant by a mediator, whether in general everyone can become a mediator or only certain ones. If you look back, the mediator, in this case, is differentiated into two situations, the mention of the mediator independently (Article 6 paragraph (3) of Law Number 30 of 1999) and the mention of the appointed mediator from an alternative dispute resolution institution as stated in the provisions of Article 6 paragraph (4) Law No. 30 of 1999.

The definition mediator appears in Article 1 point 2 of the Supreme Court Regulation (Perma) Number 1 of 2016 concerning Mediation Procedures in Courts which then divides the mediator into 2 (two) types; Judge Mediators and Certified Mediators. When referring to the Perma, the terms of the mediator are very limited, even though the meaning of the mediator according to KBBI Online is intermediary/liaison (Badan Pengembangan dan Pembinaan Bahasa, 2016). Then the question is, whether this Perma No.1 of 2016 can be the basis for the explanation of Law Number 30 of 1999 regarding the definition of a mediator. If referring to the concept of tiered norm theory where each norm must have a dependence on the norm above, then Supreme Court Regulation Number 1 of 2016 and Law Number 30 of 1999 are two sectoral regulations with different contexts and objectives. This is based on the following considerations: first, in the preamble, the Supreme Court Regulation Number 1 of 2016 is not found in Law Number 30 of 1999; and second, in the Supreme Court Regulation No.1 of 2016, nothing is mentioned about the nomenclature of alternative dispute resolution, but only mediation.

On the other hand, Law No. 30/1999 does not provide a comprehensive understanding of the forms and requirements of alternative dispute resolution institution. In this legal politics perspective, there is an assumption that this is an intention to create a more flexible legal basis to accommodate various types and 
forms of alternative dispute resolution institution. With the exception of alternative dispute resolution institutions in the financial sector which are commonly referred to as Alternative Dispute Resolution Institutions (LAPS) that must be registered with the Financial Services Authority (OJK) (Otoritas Jasa Keuangan, n.d.), there is also a Consumer Dispute Resolution Agency (BPSK) based on the Law Number 8 of 1999 concerning Consumer Protection. However, apart from the institutions mentioned above, the form of alternative dispute resolution institutions is basically still very open.

Even more interestingly, after the enactment of Law Number 6 of 2014 concerning Villages which placed the village government regime as a new chapter of regional autonomy development, the position of the village was originally subordinate to the central government (Isdiyanto, 2019b), and then it regained a strategic place. One of them is to strengthen the position of the Village Head who is given more authority to organize Government, to carry out Village Development, society development, and society empowerment. In this context, what becomes an important concern is the provision of Article 26 paragraph (4) letter $\mathrm{k}$ of Law Number 6 of 2014 which requires the Village Head to resolve society disputes in the village. However, in the provisions of this article, there is also no more detailed explanation regarding the form and process of dispute resolution as to what should be done.

Regarding the position of the Village Head in terms of its authority to organize and carry out mediation based on legality principles, there are several things that need to be noted:

1. The Village Head is not included as a mediator in the provisions of Perma Number 1 of 2016;

2. The Village Head has the authority as an obligation to resolve village society disputes by attribution or directly from the law which is notably higher in position than Perma No.1 of 2016 and is more specific (lex specialist) than the provisions of Law Number 30 of 1999;

3. Based on the provisions of Article 67 paragraph (1) letter of Law Number 6 of 2014, it is stated that villages have the right to determine and manage village institutions.

Based on the analysis of those regulations, placing the Village Head in the definition of a mediator is not quite right, because his position is required by law, not based on claim or willingness. Meanwhile, the concept of the mediator itself is basically not something that is mandatory, but based on agreement and requires the willingness of the parties, including the mediator himself. On the other hand, the position of the Village Head is not a law enforcer even though in the provisions of Article 26 paragraph (4) letter c of Law Number 6 of 2014 it is stated that the Village Head is obliged to maintain peace and order of the village society. This law is indeed a bit strange because the provisions of Article 26 paragraph (4) letter $d$ state that the Village Head is also obliged to enforce the laws and regulations, although then the form of enforcement is unclear. So far, from a legal perspective law enforcer has been none other than the Police, Prosecutors, Advocates, and Judges.

Referring to Christopher W. Moore's theory, there are three different types of mediators, namely (Krislov, 2017): 1). social network mediators; 2). authoritative mediators; and 3). independent mediators. The definition of social network mediators is more about people who are chosen as mediators for dispute resolution because they have a relationship with one of the parties or other parties concerned (Karmawan, 2017). Social network mediators can be chosen because of their reputation, family network, or friendship. This type of mediator can better accommodate what is meant in the provisions of Article 6 paragraph (3) of Law Number 30 of 1999.

The next is authoritative mediator; this is a mediator because of their position, influence, or legitimacy as leaders. This type of mediator resolves deliberations that are still within the scope of their authority but when he becomes a mediator, he can't use his power to unilaterally rule one party or other parties but helps bridge the parties to resolve their problems in a win-win solution (Karmawan, 2017). An authoritative mediator is usually more successful because he has a strong bargaining position to resolve the issue, and the parties will usually listen more to the authoritative mediator because of the needs in resolving disputes quickly. Following this understanding, it could be that the head of a company, the head of an Institution or agency, or an Institution has a special authority from the state to organize mediation activities such as LAPS or BPSK. The Village Head is actually included in this group because he gets legitimacy directly from the law. Although it is not specifically regulated in Perma No. 1 of 2016 regarding the position of the Village Head as a mediator, if the Village Head later performs this function and makes a Peace Agreement between the Parties to the dispute, 
which refers to the provisions of Article 36 Paragraph (1) of Perma No. 1 of 2016 concerning Villages, the Court still recognizes it, and it can be a basis for submitting (suing) a Peace Agreement. Thus, it has the power of execution.

The last one is an independent mediator; this is a mediator who has qualifications and professionalism in the field of mediation so that they are able to provide services to help resolve disputes or disputes between the parties. These mediators have received a special training and education or focus on conflict management and problem-solving. This type of mediator is more suitable for the provisions in Perma No.1 of 2016, namely mediators who have received certification from the Supreme Court. The provisions of this regulation basically have nothing to do with Article 26 paragraph 4 letter k of Law no. 6 of 2014, because the position of the Village Head is not automatically ex officio as a mediator. However, an independent mediator can actually accommodate mediation needs in villages because there are no specific regulations or specification for this.

Referring to Moore's theory which places the Village Head as an authoritative mediator or based on his power, it is more appropriate if it is called as the mediator who does not have a clear legal hook. The position of the village head with non-law enforcement means that the mediation pattern is more suitable. The use of the deliberative method with the village head as the mediator is more suited to the character and culture of the Indonesian people. Previously, before the enactment of Emergency Law Number 1 of 1951 on January 13, 1951 , in the spirit of unification of the judicial system, forms of local justice such as village courts were abolished. Village Court (dorpjustitie) is a form of justice that is carried out by Village Judges and is authorized to adjudicate small cases that are customary or village affairs based on customary law or norms that develop in local society (Arizona, 2013). The spirit of the village as a resolution to the eenflict has now emerged and is legitimized through the village law.

\section{The Urgency to Establish Village Mediation Institution in Wukirsari Village}

Javanese society itself has a culture for dispute resolution, which is usually called rembugan, which means deciding something based on an agreement known as deliberation to reach consensus (Taufiq et al., 2017). In the Javanese idiom, it is usually stated that ono rembug dirembug; this is a form of local wisdom in settling disputes in Javanese rural societies in general by deliberation or discussing it well with all the disputing parties (Rahayu et al., 2016). The concept of consensus deliberation is also one of the bases for resolving disputes or disputes in Wukirsari Village by using the Pamong as a mediator.

According to Fery Sanawan, the term Pamong itself is now formalized as Village Officials, which is relatively the same in general terms as other villages in Bantul Regency. Village Officials or Pamong are at the forefront of serving and maintaining order in the society because they have been granted rights from the village. Furthermore, Fery Sanawan said:

"Village officials or Pamong get welfare with Siltap (Fixed Income) which is in accordance with the UMR (Regional Minimum Wage) and Bengkok Sawah. Then regarding the formal main tasks and functions, they are already running well, and for non-formal, it is a bridge between the village (village government) and the society. " (Interview with Fery Sanawan, 07/07/2020)

Tanah bengkok is commonly referred to as an advantage, as the right of a Pamong or Village Officials. For his position he has the right to withdraw the produce from the land as long as he is still being a Pamong or Village Officials. It is prohibited for him to trade the land or to pawn it, and if the term of his position is over, Tanah bengkok must be returned (Abubakar, 2013).

Referring to Article 26 paragraph (4) letter k of Law Number 6 of 2014, the one who has the authority to resolve citizen disputes is the Village Head, not the Pamong. There is no regulatory obligation for the Pamong to do so, but in fact in this case the Village Head can delegate the authority to other Village Officials.

The delegation's authority is the authority of an Institution or structure from the other government institution's authority which is equal or higher (Rini, 2016). Another opinion places delegation as a form of bestowing of authority from government officials to other officials to make decisions on their own responsibility (Rokhim, 2013) juridically in accordance with the provisions of Article 1 number 23 of Law Number 30 of 2014 concerning Government Administration which states, "Delegation is a bestow of authority from higher

Sodality: Jurnal Sosiologi Pedesaan | Vol. 9 (02) 2021 
government agencies and/or officials to lower government agencies and/or officials with responsibility and accountability fully transferred to the delegation recipient."

Referring to those concepts and regulations, the Village Officials who resolve the problems of the villagers must get a delegation from the Village Head in written form so that the limits of their authority and the basis for their enforcement (legality principle) are clear. However, the results of the research showed there is no regulation (regeling) or a Decree (beschikkig) which leads to the giving of a delegation from the Village Head to other Village Officials to be obliged to resolve disputes among the villagers. This must be a concern because the position of the Village Officials or Pamong is very important, especially as a representation of the Village Government among villagers in realizing social order, peace, and dispute resolution. So far, this aspect has only been carried out organically (non-formal) as conveyed by Fery Sanawan as the Head of the Wukirsari Village Government.

Fery Sanawan himself sees the importance of having a special institution in helping solve problems in the society, so it can help the village government improve the services that exist in the society. So far, the settlement of residents has been resolved organically without understanding in detail the legal aspects and impacts arising from the dispute. Fery continued, there is a form of community dispute resolution institution at the village level in Panggungharjo Village called the Panggungharjo Village Mediation Institute, thus the Wukirsari Village Government is deemed necessary (urgent) to form a similar institution, as he conveyed, "It is necessary that an institution assist village officials to go directly to the society, in order to solve problems that occur in the society by mediation." (Interview with Fery Sanawan, 07/07/2020)

The dispute settlements that have been carried out informally without being equipped with scientific standards are not sufficient. In fact, there was an affair that was openly mediated by the Village Government which resulted in the death of the perpetrator, in which he felt ashamed. In line with Fery Setiawan, Susilo Hapsoro emphasized:

"The need for the ability to mediate is urgent in this village, ignorance of the techniques and methods of mediating instead of solving it can actually add more problems. In addition, the village government has only been called without understanding the proper procedures; therefore, the institutionalization of village mediation institutions will later greatly help the village government as well as the people of the Wukirsari village society." (Interview with Susilo Hapsoro, Wukirsari Village, 07/07/2020)

Muhammad Affan, who now serves as Dukuh Cengkehan, who is one of the youngest Dukuh in Wukirsari Village, also feels the difficulty in mediating. Once upon a time when he was the head of the Youth Organization (Muda Mudi) Dusun Cengkehan, there was a problem between the residents and Muda Mudi related to the unpleasant actions of one of the residents whose words offended the Muda Mudi. The problem was tried to be resolved by mediating, but when it was held the atmosphere was not conducive, and in fact it was the opposite, as he stated:

"It is difficult for us as a Dukuh to resolve society problems informally, because sometimes it is not solving problems but it can add more problems. In the past, when I was the head of the Youth Organization, I was going to solve the problem, the parties even invited people to come together, claiming as a lawyer or something, so our difficulty was we did not understand the law. For this reason, it is very important that a formal village mediation institution be formed and the Dukuh or pamong are given good information of the procedure for this mediation so that we will also get a legal protection." (Interview with Muhammad Affan, Wukirsari Village, 07/07/2020)

If there is no formal institutionalization of the village, then residents will lead to the formation of their own systems that can develop outside the control of the village government. According to Susilo Hapsoro, there has been a form of association called 'Garda' which is a youth response in Wukirsari Village for social stability. Sanarwan added that Garda has also developed and has its own way of resolving various conflicts, although in practice there is no specific method with clear regulatory standards. It is also feared that it will result in excessive actions which are against the law.

Based on the above analysis, Wukirsari Village is one of the interesting places to develop a dispute resolution system based on local values and culture, so that it has not only strong social legitimacy but also strong juridical 
legitimacy. Responding to this, it is necessary to develop an institution of the Wukirsari Village Mediation Institution whose system and form are in accordance with the situation and conditions of the Wukirsari Village society and not against the applicable law.

\section{A Model for Establishing Village Mediation Institution in Wukirsari Village}

In the previous analysis, it was explained that there is no single definitive model for alternative dispute resolution institutions. This also applies to the definitive form and model of village mediation institution. Therefore, it is necessary to conceptualize a form of institutionalization of village mediation institutions that can be developed in Wukirsari Village which is of course in accordance with the situation and conditions of the village society.

The model for alternative dispute resolution institutions will not only accommodate the existence of village officials and village heads, but involve the wider community. As stated by Susilo Hapsoro, the real power lies in the community itself thus the involvement of pamong and community leaders is the most important thing in the formation of this institution (Hapsoro, 2020). He continued, these pamong and figures are at the forefront of solving various problems in society, both today and in the future.

Reflecting on the form of similar institutions in other places, one of them is the Bale Mediasi established by the Governor of West Nusa Tenggara. According to Dr. H. Zulkieflimansyah as the Governor of West Nusa Tenggara, the goal of Bale Mediasi is to reduce and reconcile various conflicts or disputes outside the court; therefore, they can get the blessing of being baldatul thayyibatun wa rabbn ghafur. (Hernawardi, 2020) The legitimacy of Bale Mediasi itself is based on West Nusa Tenggara Governor Regulation (Pergub NTB) Number 38 of 2015 concerning Bale Mediasi, which in its preamble or consideration is to resolve disputes based on or accommodate local wisdom values. In its preamble, this Regulation is also based on Law Number 30 of 1999 concerning Arbitration and Alternative Dispute Resolution.

There are not many references or studies related to Bale Mediasi to discuss, but through the West Nusa Tenggara Governor Regulation, the model and direction of this institution can be seen. If we look at it, it turns out that Bale Mediasi is not only at the provincial level, but can also be developed at the village level. This can be seen in Article 3 of the West Nusa Tenggara Governor Regulation Number 38 of 2015, where the purpose of establishing Bale Mediasi is to carry out the function of coaching and coordination and facilitate the establishment of mediation Institution in the society according to local wisdom. Furthermore, Article 5 a quo also states that Bale Mediasi is formed in provinces or regencies / cities or villages / sub-districts. Especially for those under the province, they can even use a name other than Bale Mediasi. According to H. Lalu Mariyun, Chairman of the West Nusa Tenggara Bale Mediasi, he said that until now there have been at least 1,162 Bale Mediasi spreading throughout West Nusa Tenggara (Hariannusa.com, 2020).

Another mediation institution that can be seen is in Panggungharjo Village, it is called the Panggungharjo Village Mediation Institute. This institution that has been in existence since 2016 has the intent and purpose of resolving various problems that exist in the Pangunggharjo Village society. The concept of the Panggungharjo Village Mediation Institute is the delegation of authority to resolve society disputes from the Head of Panggungharjo Village as stipulated in Article 26 Paragraph (4) letter k of the Law Number 6 of 2014 concerning Village. The Panggungharjo Village Mediation Institute has a simpler system as illustrated in Figure 1. 


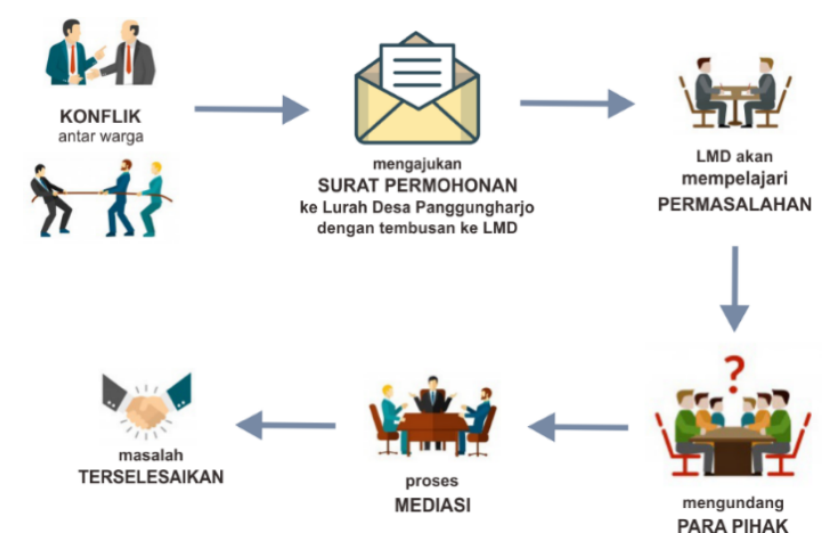

Figure 1. Flow Chart of the Panggungharjo Village Mediation Institute (Aji, 2019)

Referring to the Panggungharjo Village Mediation Institution, the existence of a similar establishment mediation institute in other regions or villages is very possible and applies to the Wukirsari Village area. So, what is needed next is how the institutional model will be formed according to the conditions and situations in Wukirsari Village.

The first thing to pay attention to is the cultural aspect, especially the values that develop in society. It is necessary to realize that this traditional culture is basically an identity that needs to be protected (Wedhitami \& Santoso, 2014). There are several things here that become the focus, such as Javanese culture which emphasizes deliberation and the participation of the Pamong or Village Officials. The Wukirsari Village Mediation Institution will have to prioritize the deliberation pattern by placing the Village Officials as executors in their respective regions. Based on the interview with Fery Sanawan, it was stated that the main function of the Wukirsari Village Mediation Institute is as a forum for the development and empowerment of the Village Officials which will later go directly to the society.

It turns out that unlike the Panggungharjo Village Mediation Institution which places mediators directly at the village level, the development of the Wukirsari Village Mediation Institution does not place authoritative mediators at the village level but at the lower level through the Village Officials or Pamong. If the Pamong can't resolve it, then the Wukirsari Village Mediation Institute will take over the case.

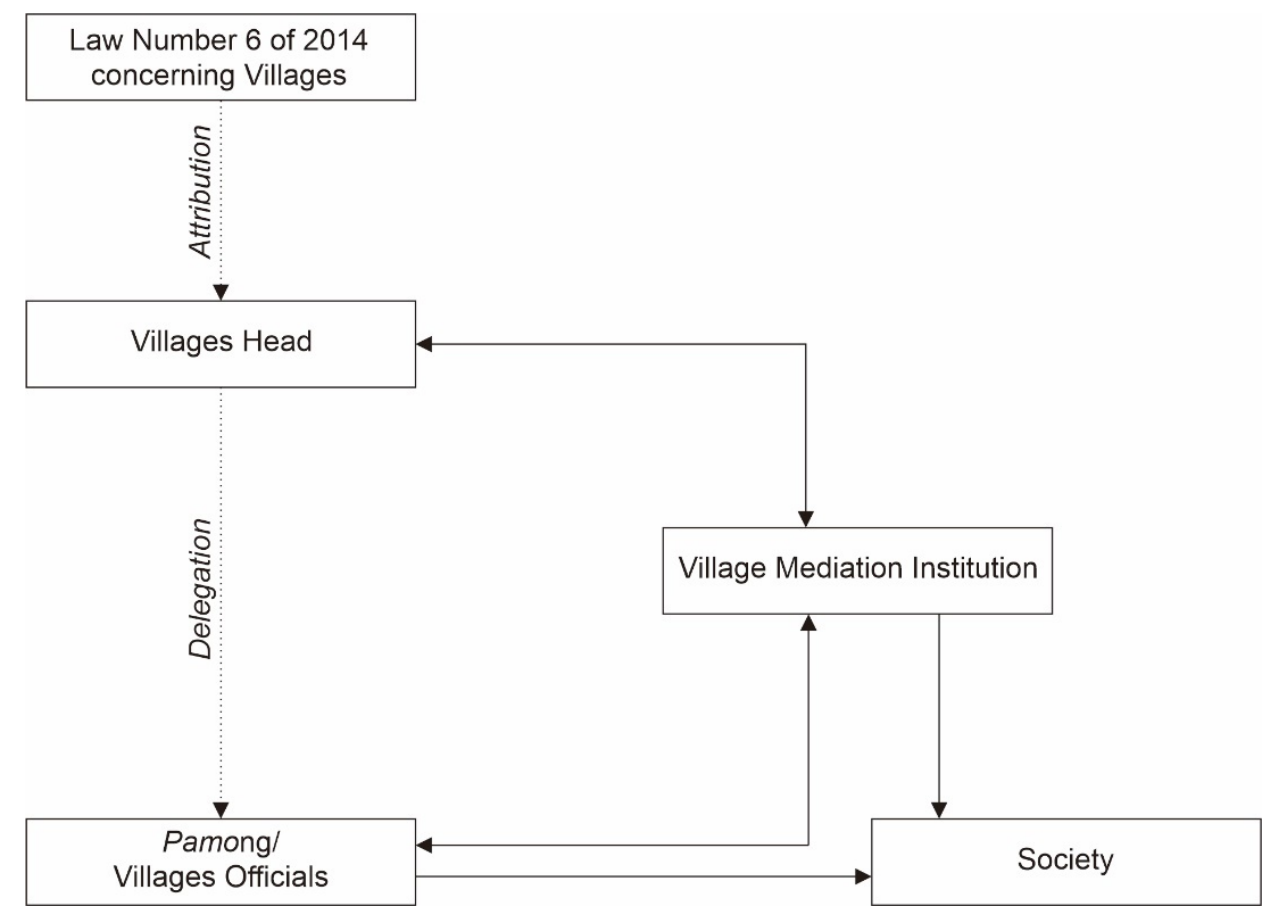

Figure 2. Authority and Society Relations Scheme 
Based on Figure 2, there are two relationships from village to the society, namely the Village Officials and the Wukirsari Village Mediation Institution. Basically, it still refers to a tiered pattern, from the Pamong then to the Wukirsari Village Mediation Institution, but for special cases that can cause more serious impacts, the Wukirsari Village Mediation Institution can immediately intervene to help solve the problem.

Furthermore, in the case of the Wukirsari Village Mediation Institution, there are several things that need to be considered, such as the position and authority of the Village Head as well as the expert institutions that will help. The village head in the authority of the village society gets high social legitimacy, so he must be able to lead, protect, and provide protection to the village society. Referring to the provisions of Article 26 paragraph (4) letter k of Law Number 6 of 2014, only the Village Head has the authority to resolve problems, and in this case, this authority if later is delegated to the Pamong or Village Officials, there has also been a transfer of responsibility for this action. However, the position of the Village Head in a material manner can't be negated easily. Even though later the authority has been given formally and procedurally through a Village Head Regulation or Village Regulation, materially the Village Head in certain conditions and situations must participate in the dispute resolution process.

As a society stakeholder, the Village Head is expected to be able to harmonize peace and order so that peace can be achieved in society (Nainggolan, 2018). This delegation must be arranged in such a way that the Village Head can continue to position himself as the organizer of peace and order in society.

As stated by Fery Sanawan, the existence of the Wukirsari Village Mediation Institution is also filled with or at least accompanied by professionals who also become partners; thus, the pattern of guidance and development of Village Officials can be more effective, as he said,"Special institutions (Village Mediation Institutions) in assisting the transfer of knowledge or consulting agencies, to find out concepts, technical solutions and as a driving force for the society directly from the Village Officials". (Interview with Fery Sanawan, Wukirsari Village, 07/07/2020)

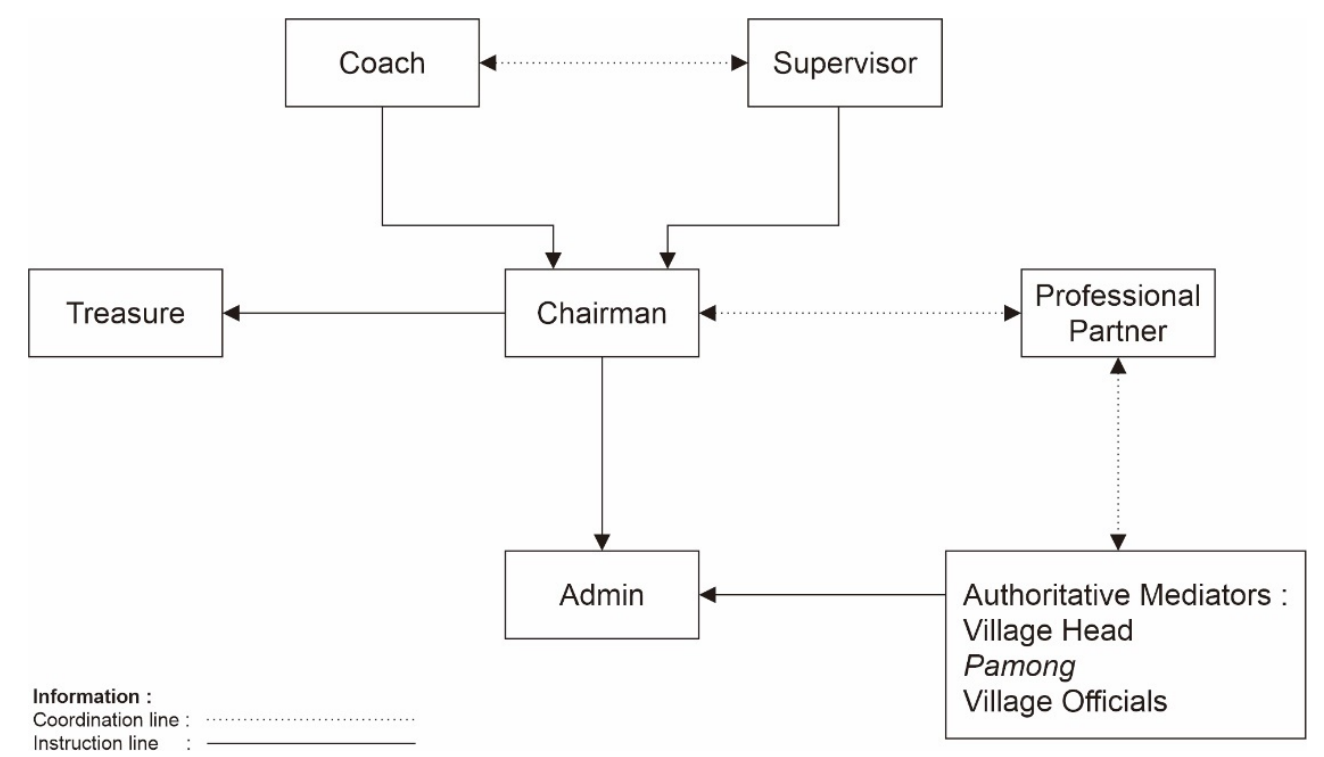

Figure 3. The structure concept of the Wukirsari Village Mediation Institution based on analyze

Referring to this situation, the Wukirsari Village Mediation Institution later will need to have a coach who comes from professionals or have partnerships with other parties who have competence in the field of mediation so that they are able to participate in the development of the Wukirsari Village Mediation Institute. In addition, as we can see in Figure 3, there needs to be a supervisor team consisting of village leaders whose function is to maintain the integrity and performance of the Wukirsari Village Mediation Institute.

\section{CONCLUSION}

The Wukirsari Village Government has an urgency to form a Village Mediation Institution because it can accommodate the needs of village communities in dispute resolution. The analysis above is based on the fact that various village disputes need to be handled by special institutions to ensure effectiveness. The Village Government itself has strong legal authority due to the provisions of Law Number 6 of 2014 concerning 
Villages provide the authority to settle community disputes. In terms of the village institution of mediation, the provisions of Law Number 30 of 1999 concerning Arbitration and Alternative Dispute Resolution especially which is related to the mediation process, as well as Perma No. 1 of 2016, also accommodates the acknowledgment of the peace agreement which is a product of the Village Mediation Institution. The Village Mediation Institution is not a judicial institution, so it is not contradictory to the existing legislation; on the other hand, the existence of this institution can help reduce the number of caseloads in the court.

The institutional model of the Village Mediation Institution in Wukirsari Village must be balanced, especially by involving the Pamong or Village Officials. In addition, community elements also need to be involved, such as community leaders and youth leaders; therefore, they can more widely to reach the village society and to be more responsive. From the empirical data tracing, it can be concluded that rural communities need legitimacy for the institutionalization of social safety systems. In this regard, Village Mediation Institutions can be a forum to accommodate the institutionalization of dispute resolution that has been developed organically. This pattern of institutionalization cannot be exercised carelessly; it needs training and assistance (professional elements) systematically; thus, it does not have an impact on increasing the social vulnerability or aggravate the existing conflicts. The community has culturally a mediation mechanism (more on deliberation), but has not yet had the capacity for mediation techniques and also post-mediation outcome such as technique of making a good and correct peace agreement. On the other hand, the legitimacy of this institution is also needed, especially from the village government to provide legal certainty for the village mediator. In terms of institutional formation, the Village Mediation Institution in Wukirsari Village can be based on the Wukirsari Village Regulation which also accommodates the mentoring role of professionals so that their functions and roles can be more effective and efficient in resolving disputes in the Wukirsari Village Society.

\section{Suggestions}

1. A Village Regulation should be made related to the establishment of a Village Mediation Institution in Wukirsari Village by involving all elements of society so that it will run according to the characters and values that exist in the society;

2. The Regional Government of Bantul Regency or the Provincial Government of the Special Region of Yogyakarta may make a Regent/Governor Regulation which contains Village establishing a Village Mediation Institution as part of efforts to control stability and to create security, peace, and order of the village people;

3. The Supreme Court should revise Regulation No. 1 of 2016 concerning Mediation Procedures in Courts by including the provisions of Law Number 30 of 1999 concerning Arbitration and Alternative Dispute Resolution and Law Number 6 of 2014 concerning Villages as a consideration so that the understanding of the mediator is not only limited to Judge Mediators and Certified Mediators but also to authoritative mediators or other mediators.

\section{ACKNOWLEDGEMENT}

The author would like to thank Universitas Ahmad Dahlan for providing the opportunity to serve as a lecturer so that we can carry out various kinds of research that are useful for civilization. A great gratitude is also expressed to the Wukirsari Village Government, Imogiri, Bantul for giving the author access to conduct research at that village and also to the people who have assisted in this writing process until its completion.

\section{REFERENCES}

Abubakar, L. (2013). Revitalisasi Hukum Adat Sebagai Sumber Hukum Dalam Membangun Sistem Hukum Indonesia. Jurnal Dinamika Hukum, 13(2), 319-331. https://doi.org/10.20884/1.JDH.2013.13.2.213

Arizona, Y. (2013). Kedudukan Peradilan Adat dalam Sistem Hukum Nasional. Retrieved July 12, 2020, from https://www.academia.edu/3723907/Kedudukan_Peradilan_Adat_dalam_Sistem_Hukum_Nasional?aut $\mathrm{o}=$ download 
Asshiddiqie, J. (2011). Gagasan Negara Hukum Indonesia. Retrieved July 12, 2020, from https://www.pngunungsitoli.go.id/assets/image/files/Konsep_Negara_Hukum_Indonesia.pdf

Badan Pengembangan dan Pembinaan Bahasa. (2016). KBBI Daring. Retrieved July 12, 2020, from https://kbbi.kemdikbud.go.id/entri/

Bakker, A., \& Zubair, A. C. (1990). Metodologi Penelitian Filsafat. Kanisius, Yogyakarta.

Basuki, U. (2017). Desa Mawa Cara Negara Mawa Tata: Dinamika Pengaturan Desa Dalam Sistem Ketatanegaraan Indonesia. Jurnal Al-Mazahib, 5(2), 321-344. http://ejournal.uinsuka.ac.id/syariah/almazahib/article/view/1424

Benuf, K., \& Azhar, M. (2020). Metodologi Penelitian Hukum sebagai Instrumen Mengurai Permasalahan Hukum Kontemporer. Gema Keadilan, 7(1), 20-33. https://doi.org/https://doi.org/10.14710/gk.7.1.2033

Darumurti, K. D. (2017). Karakter Ilmu Hukum: Pendekatan Fungsional dalam Kaitan dengan Pendidikan Hukum. Refleksi Hukum, 2(1), 191-211. https://doi.org/10.24246/jrh.2017.v1.i2.p191-212

Dil. (2019). Mahfud MD Khawatir Kepastian Hukum Mulai Dikesampingkan. Retrieved July 12, 2020, from jpnn.com/news/mahfud-md-khawatir-kepastian-hukum-mulai-dikesampingkan

Erdianto, K. (2018). ICW: Dalam Enam Tahun, 28 Aparat Lembaga Peradilan Ditangkap KPK. Retrieved July 12, 2020, from https://nasional.kompas.com/read/2018/11/30/13512521/icw-dalam-enam-tahun-28aparat-lembaga-peradilan-ditangkap-kpk?page=all

Hariannusa.com. (2020). Resmikan Bale Mediasi, Gubernur NTB Harap Tidak Semua Persoalan Berakhir di Meja Hijau. Retrieved July 12, 2020, from https://hariannusa.com/2020/01/08/resmikan-bale-mediasigubernur-ntb-harap-tidak-semua-persoalan-berakhir-di-meja-hijau/

Hernawardi. (2020). Ini Tujuan NTB Bangun 1.162 Balai Mediasi. Retrieved July 12, 2020, from https://www.gatra.com/detail/news/465097/hukum/ini-tujuan-ntb-bangun-1162-balai-mediasi

Indriana, H., A Kinseng, R., \& Adriana, G. (2016). Dinamika Kelembagaan Pertanian Organik Menuju Pembangunan Berkelanjutan. Sodality: Jurnal Sosiologi Pedesaan, 4(2), 192-207. https://doi.org/10.22500/sodality.v4i2.13652

Isdiyanto, I. Y. (2019a). Dekonstruksi Pemahaman Pancasila: Menggali Jati Diri Hukum Indonesia. UGM Press, Yogyakarta.

Isdiyanto, I. Y. (2019b). Village Sovereignty in Dispute Resolution after Law No 6 of 2014 concerning Village. Media Hukum, 26(2), 223-239. https://doi.org/10.18196/jmh.20190136

Karmawan. (2017). Diskursus Mediasi dan Upaya Penyelesaiannya. KORDINAT, XVI(1), 107-126. https://repository.uinjkt.ac.id/dspace/bitstream/123456789/54580/1/6457-17153-1SM\%20\%2813\%29.pdf

Krislov, J. (2017). The Mediation Process: Practical Strategies for Resolving Conflict (4th edition) Christopher W. Moore (Jossey-Bass, 2014). Equinox, 2(1), 84-88. https://doi.org/10.1558/mtp.33140

Mahkamah Agung Republik Indonesia. (2010). Cetak Biru Pembaharuan Pengadilan 2010-2035. Retrieved July 12, 2020, from https://www.mahkamahagung.go.id/media/198

Marzuki, P. M. (2010). Penelitian Hukum (VI). Prenada Media Group, Jakarta.

Muljana, S. (2006). Tafsir Sejarah Nagara Kretagama. LKiS, Yogyakarta.

Nainggolan, S. D. P. (2018). Kedudukan Kepala Desa sebagai Hakim Perdamaian. UBELAJ, 3(1), 54-67. DOI: https://doi.org/10.33369/ubelaj.3.1.54-67.

Ningsih, A., Faisal, \& Adwani. (2019). Kedudukan Notaris sebagai Mediator Sengketa Kenotariatan Terkait 
dengan Kewajiban Penyuluhan Hukum. Jurnal Ilmiah Kebijakan Hukum, 13(2), 201-228. https://doi.org/10.30641/kebijakan.2019.v13.201-228

Nursaid, A., \& Armawi, A. (2016). Peran Kelompok Batik Tulis Giriloyo dalam Mendukung Ketahanan Ekonomi Keluarga. Jurnal Ketahanan Nasional, 22(2), 217-236. https://doi.org/10.22146/jkn.12507

Otoritas Jasa Keuangan. (n.d.). Lembaga Alternatif Penyelesaian Sengketa. Retrieved July 12, 2020, from https://www.ojk.go.id/id/kanal/edukasi-dan-perlindungan-konsumen/Pages/Lembaga-AlternatifPenyelesaian-Sengketa.aspx

Pemerintah Kabupaten Bantul. (n.d.). Desa Wukirsari. Retrieved September 16, 2020, from https://kecimogiri.bantulkab.go.id/

Priyatingsih, N. (2019). Tingkat Tutur sebagai Sarana Pembentukan Pendidikan Karakter. Kawruh: Journal of Language Education, Literature, and Local Culture, 1(1), 47-63.

Rahayu, S. L., Mulyanto, \& Mayastuti, A. (2016). Penguatan Fungsi Kepala Desa Sebagai Mediator Perselisihan Masyarakat Di Desa. Yustisia Jurnal Hukum, 5(2), 340-360. https://doi.org/10.20961/yustisia.v95i0.2812

Rahmatullah, I. (2017). Menerobos Sekat Administrasi Peradilan. Refleksi Hukum, 2(1). 117-130. https://doi.org/https://doi.org/10.24246/jrh.2017.v1.i2.p117-130

Riffai, \& M, S. (2018). Istilah Dalam Proses Pembuatan Wayang Kulit Di Dusun Karangasem, Desa Wukirsari, Kecamatan Imogiri, Bantul, Yogyakarta. CARAKA, 4(2), 115-130.

Rokhim, A. (2013). Kewenangan Pemerintahan Dalam Konteks Negara Kesejahteraan (Welfare State). Jurnal Ilmiah Dinamika Hukum, XIX(36), 136-148. http://www.infodiknas.com/wpcontent/uploads/2016/01/Kewenangan-Pemerintahan-Dalam-Konteks-Negara-Kesejahteraan-WelfareState-.pdf

Scholten, P. (2002). Struktur Ilmu Hukum. Translated y B. Arief Sidharta. Retrieved July 12, 2020, from http://www.paulscholten.eu/cp/wp-content/uploads/2013/09/Judul-Struktur-Ilmu-Hukum-geheel.pdf

Siswanta, L. (2008). Kontribusi Home Industry dalam Meningkatkan Kesejahteraan Sosial Ekonomi Keluarga (Studi Kasus di Desa Wukirsari, Imogiri). Aknemika UPY, 2. Retrieved July 12, 2020, from http://repository.upy.ac.id/2291/1/akmenia2.pdf

Soehadha, M. (2014). Wedi Isin (Takut Malu); Ajining Diri (Harga Diri) Orang Jawa Dalam Perspektif Wong Cilik (Rakyat Jelata). Religi Jurnal Studi Agama-Agama, 10(1), 1-11. https://doi.org/10.14421/rejusta.2014.1001-01

Sukirno, F. S., \& Harianto, S. (2017). Pergeseran Gaya Hidup Masyarakat Sub Urban Area Di Kota Mojokerto. Paradigma, 5(1), 1-10. https://media.neliti.com/media/publications/252998-pergeseran-gaya-hidupmasyarakat-sub-urb-af86b18e.pdf

Taufiq, M., Sarsiti, Widyaningsih, R., \& Hendriana, R. (2017). Mediasi Sebagai Penguatan Kearifan Lokal Banyumas Dalam Penyelesaian Perkara Pidana. Jurnal Media Hukum, 24(2), 137-146. https://doi.org/10.18196/jmh.2017.0089.137-146

tribratanewsbantul. (2019). Warga Sindet Gantung Diri. Retrieved July 12, 2020, from https://www.tribratanewsbantul.id/2019/02/warga-sindet-gantung-diri.html

Widihastuti, S., \& Kusdarini, E. (2013). Kajian Hak Kekayaan Intelektual Karya Perajin Batik: Studi Kasus di Desa Wukirsari Imogiri Bantul. Jurnal Penelitian Humaniora, 18(2), 145-155. https://journal.uny.ac.id/index.php/humaniora/article/view/3171/2657

Yani, A. (2018). Sistem Pemerintahan Indonesia: Pendekatan Teori dan Praktik Konstitusi Undang-undang Dasar 1945. Jurnal Ilmiah Kebijakan Hukum, 12(2), 119-135. https://doi.org/http://dx.doi.org/10.30641/kebijakan.2018.V12.119-135 